(c) Bagmut I.Yu., Galmiz O.O., Gramatiuk S.M.

UDK 6166441-006-008.6

\title{
THE PATHOPHYSIOLOGICAL MECHANISMS OF ENDOGENOUS INTOXICATION IN PATIENTS WITH THYROID CANCER*
}

\section{Bagmut I.Yu., Galmiz O.O., Gramatiuk S.M.}

Kharkiv Medical Academy of Postgraduate Education, Ukraine

In the present paper, the content of the average molecular peptides, lipid peroxidation products, oxidative modifications of proteins in the serum of patients with thyroid cancer has been studied and their prognostic value has been substantiated in optimizing of pathogenic therapy. The study involved 94 patients who were divided into 3 groups depending on the cell structure of the tumor. The results of the study revealed the increase in serum levels of malonic dialdehyde, dienes, 2,4-dinitrophenylaldo-hydrazones and 2,4-dinitrophenylketohydrugs, low molecular weight molecules and leukocyte intoxication index. It is established that the leading pathogenic mechanism of formation and decompensation of endotoxicosis in thyroid cancer patients is the accumulation of the ratio of plasma and erythrocyte fraction of substances of low and average molecular weight of plasma and red blood cells, especially their large-molecular, catabolic fraction, with violation of renal excretion of endotoxins.

Key words: average molecular peptides, lipid peroxidation products, oxidative modification of proteins, intoxication.

В роботі вивчено вміст в сироватці крові хворих на рак щитоподібної залози средньомолекулярних пептидів, продуктів перекисного окислення ліпідів, окислювальна модифікації білків і обгрунтувано їх прогностичне значення при оптимізації патогенетичної терапії. В дослідженні приймали участь 94 пацієнти, які були поділені на 3 групи в залежності від клітинної будови пухлини. Результати дослідження виявили збільшення в сироватці крові вмісту малонового діальдегіду, дієнів, 2,4-динітрофенілальдо-гідразонів і 2,4-динітрофенілкетогідразнів, молекул середньої маси і лейкоцитарного індексу інтоксикації. Встановлено, що провідним патогенетичним механізмом формування і декомпенсації ендотоксикозу у хворих на рак щитоподібної залози, є накопичення відношення плазмової $і$ еритроцитарної фракції речовин низької та середньої молекулярної маси плазми і еритроцитів, особливо їх велико-молекулярної, катаболічної фракції, з порушенням ниркової екскреції ендотоксинів.

Ключові слова: середньомолекулярні пептиди, продукти перекисного окислення ліпідів, окислювальна модифікація білків, інтоксикація.

Thyroid cancer is about $1.5 \%$ of all malignant diseases. According to $\mathrm{WHO}$, the incidence of thyroid cancer in the last 20 years has doubled, mainly due to young and middle-aged people. During the last decade after the accident at the Chernobyl Nuclear Power Plant, a significant increase in the number of patients with thyroid cancer in Ukraine has been noted. With these patients there are doctors of different specialties general surgeons, endocrinologists, surgeons, oncologists, radiologists [1-3].

Types of thyroid cancer are a special group of malignant neoplasms that develop from the follicular and parafolucular cells of this organ. Each type of thyroid cancer requires a doctor of great knowledge in the field of endocrinology, medical radiology and pathogistology. Functional activity of the thyroid gland is structurally divided between independent cell groups. These are follicular or A-cells that produce thyroxine - a hormone, mainly acting as a regulator of the process of oxidation in cells; B-cells that accumulate biogenic monoamine - serotonin; parafollicular, or C-cells that synthesize calcitonin. C-cells of the thyroid gland, which are neuroectodermal in nature, along with cells of carotid cells, adrenaline and noradrenaline derivatives of the adrenal glands, cells of the anterior lobe of the pituitary gland and other cells that produce polypeptide hormones and are capable of active accumulation of precursors of monoamines and their decarboxylation, refer to the APUDsystem (Amineprecursorand decarboxylation) [4-7].

The consequence of such a functional variety of thyroid cancer is the difference in the degree and clinical manifestation of endogenous intoxication. Also, in our opinion, the pathophysiological mechanisms of development of endogenous intoxication in these patients are different.

The toxic substances entering the body and endotoxins that are formed and accumulated, with many diseases and pathological conditions, sharply put the need to clean the "endoecological space" of the organism from the exo - and endotoxins [1-3, 5]. An important role in which the new direction in medicine plays is the ecology of the internal environment of the organism, the leading importance of which is the substantiation of the system of measures on endoecological rehabilitation of patients. Studies show that the formation of endogenous intoxication is associated with an increase in the concentration of medium weight molecules (MWM) and correlates with the stage of the disease, which can serve as an indicator of toxification of the organism. Molecules of medium mass can affect the vital functions of all systems and organs of an organism. They are structurally similar to regulatory peptides that can combine and block cell receptors, thereby changing the metabolism and their functions $[4,6-8]$.

Taking into account the foregoing, we have studied the content of the mediumsized peptides in the serum of thyroid cancer (TC) patients, the products of lipid peroxidation, the oxidative modifications of proteins, and their prognostic value has been substantiated in optimizing pathogenic therapy. In this connection, the study program envisaged the study leukocyte indexes of

\footnotetext{
* To cite this English version: Bagmut I.Yu., Galmiz O.O., Gramatiuk S.M., Titkova A.V. The pathophysiological mechanisms of endogenous intoxication in patients with thyroid cancer.// Problemy ekologii ta medytsyny. - 2018. - Vol 22, № 1-2. - P. 53-56.
} 
intoxication, in serum, lipid peroxidation products - diene conjugates and malonic dialdehyde; oxidative modification of proteins - 2,4-dinitrophenylaldo-hydrazones (2,4DNPAH) and 2,4-dinitrophenylketohydrugs (2,4-DNPKH), medium molecules.

The aim of the research was to study pathogenetic mechanisms of development of endogenous intoxication in patients with thyroid cancer.

This work is a fragment of "Cellular-molecular mechanisms of inflammation associated with chronic diseases», the state registration number 015U001186, "Pathochemical mechanisms of action of radioiodine on the organism and principles of their early diagnosis and correction", state registration number 0117U000589 KhMAPO.

\section{Materials and methods}

The study was attended by 94 patients who were diagnosed with thyroid cancer. We used the classification of the tumor cell structure used to assess the aggressiveness and rate of growth [8, 9].

According to this classification the patients were divided into 3 groups: the first group included 41 patients with papillary adenocarcinoma; II group - 32 patients with follicular adenocarcinoma; the III group consisted of 21 patients, diagnosed with low-differentiated thyroid cancer. The control group consisted of 27 patients without pathology of thyroid gland and without a history of oncological disease. The thyroid gland cancer diagnosis was verified according to histological analysis.

In order to evaluate the state of endogenous intoxication, the content of medium weight molecules (MWM) in blood plasma was determined by the screening method for Gabrielyan N. N. [14] at two wavelengths$254 \mathrm{~nm}$ (registration of a catabolic pool) and $282 \mathrm{~nm}$ (registration of anabolic pool). Malonium dialdehyde (MDA) and diene conjugates were determined by the generally accepted method Andreeva L.I. [15].

The calculation of the index of endogenous intoxication syndrome (ISEI) equal to the ratio of plasma and erythrocyte fraction of substances of low and average molecular weight (RLAMW) to urine RLAMW, calculated by the formula [16]:

ISEI = RLAMW pl. X RLAMW er. / RLAMW urine, (standart $-5.32 \pm 0.48$ ).

The level of substances of low and average molecular weight in plasma, urine and erythrocytes was determined according to the method Obolensky S.V. et al. [17]. The principle of the method is based on the determination of the absorption spectrum of the protein-free supernatant in the ultraviolet region (238-302 nm). Normally, the content of RLAMW in plasma is 6.82-10.4. c.u., in urine and in erythrocytes $-30 \mathrm{c.u}$. that is, the catabolic pool of

RLAMW plasma and urine was calculated by the formula [18 ]:

$(E 238+\mathrm{e} 242+\ldots+\mathrm{E} 258) \mathrm{X} 4$, in the norm no more than $4-5$ c.u. (10-15\% of RLAMWpl.)

To evaluate the intensity of spontaneous oxidative modification of blood serum proteins, a method modified by Dubinina et al. [7], based on the reaction of the interaction of carbonyl derivatives of proteins and shiffoes with 2,4-dinitrophenylhydrazine (DNPH) to form 2,4dinitrophenylhydrazones. For the analysis, blood serum of patients with thyroid gland cancer was taken, in the amount of $0.05 \mathrm{ml}$. Deposition of serum proteins was carried out with a $20 \%$ solution of TCO. To denatured protein, an equal volume $(1 \mathrm{ml})$ of a $0.1 \mathrm{M}$ solution of $2,4-$ $\mathrm{DNFH}$, made on a $2 \mathrm{M}$ solution of $\mathrm{HCl}$, was added. The test sample instead of 2,4-DNFH contained an equal volume of $2 \mathrm{M} \mathrm{HCl}$ solution. The incubation of the samples was carried out for 1 hour at room temperature.

For deposition of proteins, the samples were centrifuged at $3000 \times \mathrm{g}$ for $15-20 \mathrm{~min}$. The precipitate was washed 3 times with a mixture of ethanol-ethyl acetate $(1: 1)$ to extract lipids that did not react with the carbonyl groups of the oxidized proteins 2,4-DNFH. The resulting precipitate was dried. The dried precipitate was dissolved in $2.5 \mathrm{ml}$ of a $8 \mathrm{M}$ solution of urea in a boiling water bath for 5 minutes until complete dissolution. The formed 2,4-dinitrophenyl hydrazone was recorded on a spectrophotometer SF-26 at the following wavelengths: 356,370 , and $430 \mathrm{~nm}$. The number of 2,4dinitrophenylhydrazones was calculated using a molar extinction coefficient equal to $21 \cdot 10-3 \mathrm{~mol}-1 \mathrm{~cm}-1$ [12].

Statistical analysis of the results was carried out using the computer software package for statistical information processing Statistica 6.1 (StatSoft, Inc., USA).

\section{Results and discussion}

Taking into account mentioned above, we studied the content of thyroid gland cancer patients in the blood serum, mediomolecular peptides, lipid peroxidation products, oxidation modifications of proteins, and their prognostic value in the formation of endogenous intoxication. In this regard, the study program included the study of leukocyte index of intoxication, serum, products of lipid peroxidation - diene conjugates and malonic dialdehyde; oxidative modification of proteins 2,4-dinitrophenylaldo-hydrazones (2,4-DNPAH) and 2,4dinitrophenylketohydrugs (2,4-DNPKH), medium molecules.

The results of the study revealed the increase in the blood serum of patients with TC in the MDA, dienes, 2,4DNPAH, 2,4-DNPKH, MWM and leukocyte index of intoxication with different histological characteristics of the thyroid gland cancer type (Table 1).

Table 1

Indicators of endogenous intoxication in patients with thyroid cancer

\begin{tabular}{|c|c|c|c|c|}
\hline \multirow[b]{2}{*}{ Indexes } & \multicolumn{4}{|c|}{ Observation group, $\mathrm{M} \pm \mathrm{m}$} \\
\hline & $\begin{array}{c}\text { papillary } \\
\text { adenocarcinoma } \\
(n=41)\end{array}$ & $\begin{array}{c}\text { follicular } \\
\text { adenocarcinoma } \\
(n=32)\end{array}$ & $\begin{array}{l}\text { low-differentiation } \\
\text { cancer }(n=21)\end{array}$ & $\begin{array}{l}\text { Control group } \\
\quad(n=27)\end{array}$ \\
\hline MDA (мкмоль/л) & $3.8 \pm 1.5^{*}$ & $3.7 \pm 1.4^{*}$ & $4.4 \pm 1.3^{*}$ & $2.1 \pm 0.18$ \\
\hline Diens (мм/л) & $27.2 \pm 4.4^{*}$ & $19.8 \pm 4.3^{*}$ & $22.6 \pm 4.5^{*}$ & $9.2 \pm 0.67$ \\
\hline $\begin{array}{l}\text { 2,4-DNPAH (single wholesale } \\
\text { density/1g protein, } \lambda-370 \mathrm{~nm} \text { ) }\end{array}$ & $58.4 \pm 5.7^{*}$ & $56.7 \pm 4.9^{*}$ & $60.3 \pm 4.2^{*}$ & $27.3 \pm 1.87$ \\
\hline $\begin{array}{l}\text { 2,4-DNPKH (single wholesale } \\
\text { density/1g protein, } \lambda-380 \mathrm{~nm} \text { ) }\end{array}$ & $65.3 \pm 8.7^{*}$ & $66.8 \pm 7.5^{\star}$ & $64.2 \pm 6.6^{*}$ & $23.8 \pm 2.19$ \\
\hline MWM (c.u.) & $0.58 \pm 0.19^{*}$ & $0.53 \pm 0.25^{*}$ & $0.66 \pm 0.22^{*}$ & $0.22 \pm 0.03$ \\
\hline
\end{tabular}

Note: * probability is reliable $P<0.05$ 
Depending on the functional state, malonic dialdehyde in the highest degree increased in patients of the I-group by $76.4 \%$. The dietary conjugates were significantly $(p<0.05)$ higher in patients with thyroid cancer when compared with control group $83.5 \%$. Products of oxidative modification of proteins 2,4-DNPAH and $2,4-\mathrm{DNPKH}$, in all cases increased by more than $90 \%$. Particularly high levels were observed in 2,4DNPKH in patients of the 2nd group. Their concentration in serum exceeded the value of the comparison group, respectively, by $98.0 \%$. The leukocyte index of intoxication in all groups increased by more than 2.5 times.

Indicators of leukocyte index of intoxication (LII), nuclear index of intoxication (NII). The presence of intoxication associated with infectious or autoimmune process, was evaluated by the index of ratio of leukocytes and ESR (ILESR), and the relationship between the humoral and cellular parts of the immune system - by the value of the leukocyte index (LI). As a marker of reactivity of the body during inflammation, the blood leukocyte shift index (IBLS) was used (Figure 1).

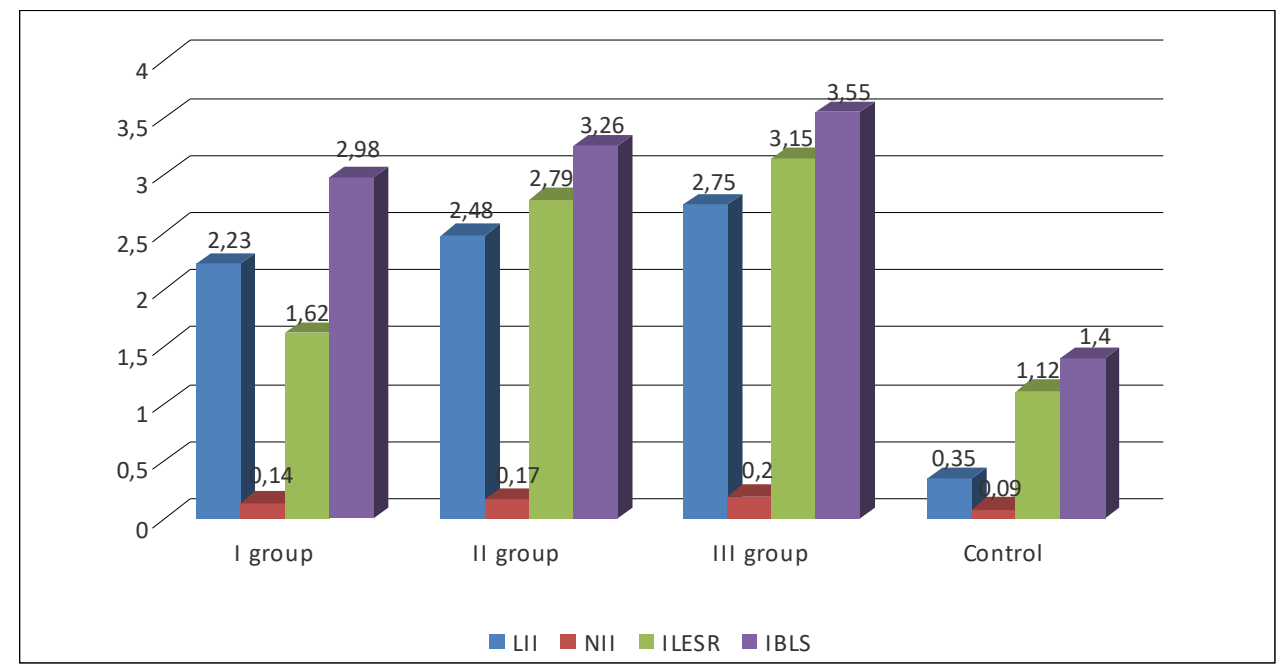

Fig. 1. The value of estimated indicators of intoxication in patients with thyroid cancer

Molecules of moderate mass increased in patients with papillary adenocarcinoma, follicular adenocarcinoma and low-differentiated cancer, respectively, by $58.3 \%$, $80 \%$ and $94.1 \%$. However, it should be noted that the average values of the studied parameters in all cases, had a large error, indicating a significant toxification of the body in conditions of thyroid cancer. The next stage of the study was an assessment of the influence of carcinogenesis on the course of endogenous intoxication. It was established that the leading pathogenetic mechanism of formation and decompensation of endotoxicosis in cancer patients is accumulation of RLAMW of plasma and erythrocytes, especially of their large molecular, catabolic fraction, with violation of renal excretion of endotoxins (Table 2).

Table 2

Indicators of endotoxicosis in patients with thyroid cancer

\begin{tabular}{|c|c|c|c|c|}
\hline \multirow[b]{2}{*}{ Indexes } & \multicolumn{4}{|c|}{ Patients with thyroid cancer } \\
\hline & $\begin{array}{c}\text { papillary } \\
\text { adenocarcinoma }(n=41)\end{array}$ & $\begin{array}{c}\text { follicular } \\
\text { adenocarcinoma } \\
(n=32)\end{array}$ & $\begin{array}{l}\text { low-differentiation } \\
\text { cancer }(n=21)\end{array}$ & $\begin{array}{l}\text { Control group } \\
\quad(n=27)\end{array}$ \\
\hline RLAMW venous plasma, c.u. & $28.02 \pm 0.15^{\star}$ & $31.03 \pm 0.24$ * & $34.49 \pm 0.25^{\star}$ & $26.55 \pm 0.21$ \\
\hline $\begin{array}{l}\text { RLAMW } 238-258 \mathrm{~nm} \text { venous } \\
\text { plasma, c.u. }\end{array}$ & $18.16 \pm 0.5^{\star}$ & $19.8 \pm 4.3^{*}$ & $20.19 \pm 0.36^{*}$ & $17.86 \pm 0.42$ \\
\hline RLAMW venous er., c.u. & $31.47 \pm 0.21^{*}$ & $33.48 \pm 0.2^{*}$ & $42.26 \pm 1.2^{*}$ & $31.24 \pm 0.25$ \\
\hline RLAMW urine, c.u. & $80.17 \pm 1.19^{*}$ & $58.71 \pm 1.2^{*}$ & $64.2 \pm 6.6^{*}$ & $36.84 \pm 1.46$ \\
\hline
\end{tabular}

Note: * probability is reliable $P<0.05$

The most pronounced changes in endogenous intoxication were found in patients with follicular adenocarcinoma of RLAMW venous plasma, in the group of patients with papillary adenocarcinoma, the most informative indicators of RLAMW venous erythrocytes and RLAMW steel $238-258 \mathrm{~nm}$ in plasma. Significant differences in urine RLAMW were observed in patients with low-differentiated cancer, which has an important prognostic value.

\section{Conclusions}

Thus, the results of the study indicate that at $\mathrm{TC}$, there is an auto-intoxication of the body, the severity of which is closely related to the functional state. The leading pathogenetic chains of mechanisms for the formation of metabolic syndrome in patients with thyroid cancer can be activation of free radical processes, lipid peroxidation, oxidation modification of proteins, nucleic acids, and others. macromolecules, damage to the structural and functional state of cell membranes and intracellular organelles, inhibition of bioenergetics against the background of separation of breathing and oxidative phosphorylation. In patients with stage III of the TC there is a tendency to increase the calculated indicators of intoxication, but it can be assumed that in these patients, endogenous intoxication is in a subcompensated state.

The index of ISEI can be a prognostically significant indicator in the diagnosis of metabolic syndrome, 
determining the severity of the disease, the effectiveness of pathogenetic therapy, as well as the choice of direction and volume of surgical intervention.

\section{References}

1. Ahn D. Clinical relationship between Hashimoto's thyroiditis and papillary thyroid cancer / Ahn D., Heo S.J., Park J.H. // J. ActaOncol. - 2011. - Vol.50. - P.1228-1234.

2. Bychkov A. Patterns of FOXE1 expression in papillary thyroid carcinoma by immunohistochemistry / Bychkov A., Saenko V., Nakashima M. // J. Thyroid. - 2013. - T.23. P.817-828.

3. French J.D. Programmed death-1+ $T$ cells and regulatory $\mathrm{T}$ cells are enriched in tumor-involved lymph nodes and associated with aggressive features in papillary thyroid cancer. / French J.D., Kotnis G.R., Said S. // J. ClinEndocrinolMetabol - 2012. - Vol.97. - P. 934-943.

4. Worden F. Treatment strategies for radioactive iodinerefractory differentiated thyroid cancer // TherAdv Med Oncol. - 2014. - Vol.6. - P. 267-279.

5. Chowdhury S. Programmed death-ligand 1 overexpression is a prognostic marker for aggressive papillary thyroid cancer and its variants / Chowdhury S., Veyhl J., Jessa F. // Oncotarget. - 2016. - Vol.7. - P. 32318-32328.

6. Malev A.L. "The role of oxidative modification of proteins in the diagnosis of endogenous and exogenous mental disorders." Dis. cand. med. sciences. Kharkov - 2009.

7. Oxidative modification of human serum proteins, the method of its determination / E.E. Dubinina, S.O. Burmistrova, D.A. Khodov, I.G. Porotov // Vopr. medical chemistry. - 1995. - T. 41, №. 4. - P. 24-26.

8. Dubinina E.E. Products of oxygen metabolism in the functional activity of cells (life and death, creation and destruction). // Physiological and clinical-biochemical aspects. - 2006. - St. Petersburg: Publishing house "Medical Press". - P. 276-282.

9. Wang X. PD-L1 expression in human cancers and its association with clinical outcomes. // J. Onco Targets Ther. 2016. - Vol.9. - P.5023-5039.
10. Papaioannou N.E. Harnessing the immune system to improve cancer therapy / Papaioannou N.E., Beniata O.V., Vitsos P., Tsitsilonis O., Samara P. // Ann Transl Med. 2016. - Vol.4. - P.261-267.

11. Romano $\mathrm{E}$. The therapeutic promise of disrupting the PD1/PD-L1 immune checkpoint in cancer: unleashing the CD8 T cell mediated anti-tumor activity results in significant, unprecedented clinical efficacy in various solid tumors. / Romano E., Romero P. // J. Immunother Cancer. 2015. - Vol.3. - P.10-15.

12. Slow L.M., Jones R., Randolph G. and others. (2003) History of thyroid and parotid gland surgery. Clin endocrinol. and Endocrine Surgery, 3 (4): 62-69.

13. Thyroid surgery (2008) / Ed.: S.Y. Rybakova, VO Shidlovsky, IV Komisarenko, MP Pavlovsky Ukrmedkniga, Ternopil. $-423 \mathrm{pp}$.

14. Gabrielyan N.I., Lipatova V.I. Opyt ispol'zovaniya pokazatelya srednich molekul $\mathrm{v}$ krovi dlya diagnostiki nefrologicheskich zabolevaniy u detey // Lab. delo. - 1984. - № 3. - S. 138-140.

15. Andreeva L.I., Kozhemyakin L.A., Kishkun A.A. Modification of the method for determining lipid peroxides in the test with thiobarbituric acid // Laboratornoe delo. - 1988. №11. - P. 41-43.

16. Grigor'ev E. V. Diagnosticheskaya i pro-gnosticheskaya znachimost' biochimicheskich markerov ostrogo povrezhdeniya legkich / E. V.Grigor'ev, Yu. A.Churlyaev, D. L. Shu-kevich, L. E. Shukevich, A. S. Razumov /I Obschaya reanimatologiya. - 2006. - T.2 , № 4. - S. 48 53

17. Belyakov N. A.. Aktivaziya komponentov kallikrein kininovoy sistemy krovi $v$ kriticheskich sostoyaniyach $\mathrm{i}$ ich sorbziya na aktivirovannych gulyach / N. A. Belyakov, C. B. Obolenskiy, L. K. Shershneva i [dr.] // Vestnik Chirurgii. - 2001. - № 9. - C. 120 - 122.

18. Zitogeneticheskie metody. Kuznezova T.V. pod redakziey Karpischenko A.I. //Medizinskie laboratornye technolo-gii. SPb:Intermedika. - 2002. - T.2. - C. 123-148.

Матеріал надійшов до редакції 20.02.2018 